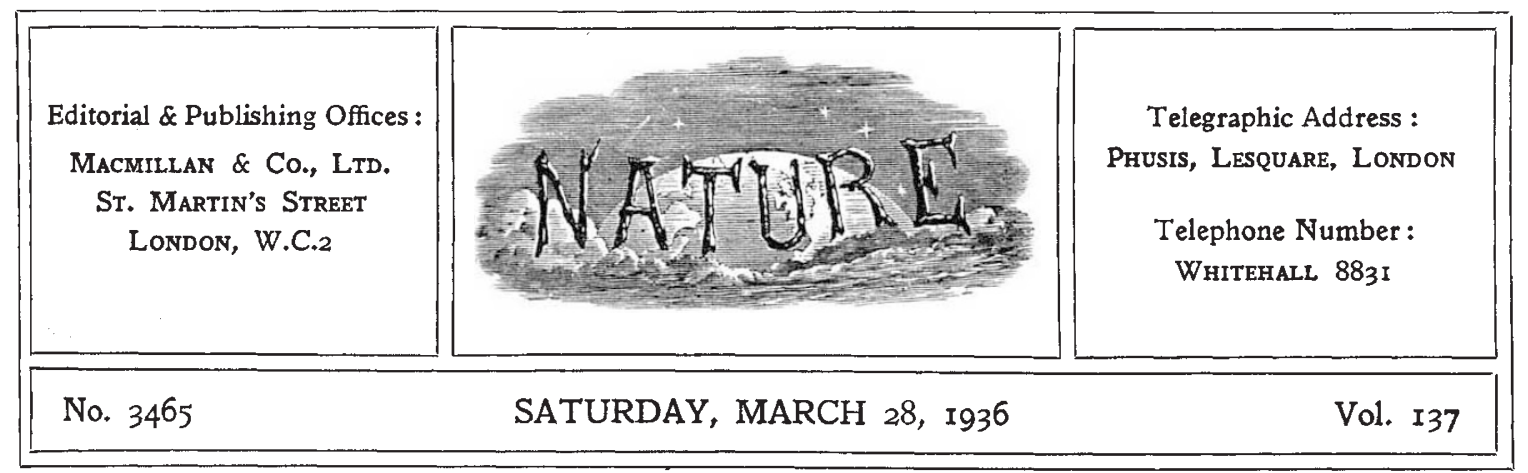

\title{
Defence and Industrial Efficiency
}

$\mathrm{T}$ HE growth of economic nationalism during the last four or five years has in itself been directly responsible for some deterioration in the international situation through its effect on international trade and economic policy. Much more serious, however, has been its influence on the development of re-armament policies mutually inconsistent with and opposed to the principles of collective security. Formidable as are these dangers, they are but slight compared with those which arise from the orientation of national policy in certain countries in accordance with a militaristic spirit and a glorification of war itself, closely allied to the militarism which in pre-War Germany was a primary factor in precipitating conflict.

Not even the ruthlessness with which youth is being mobilised for war almost from the cradle in such countries as Germany and Italy, or the re. percussions of the Italian-Abyssinian conflict have, however, brought home so clearly to the public in Great Britain the necessity for visualising national defence in terms of man-power and industrial efficiency and not merely in terms of air, military or naval forces and their armaments, as the publication of the Government's White Paper on defence* has done. The survey of international affairs and of re-armament in other countries which forms the first part of the Statement, disturbing as it may be, is almost completely overshadowed by the third and fourth sections, which deal with the coordination of defence and the means of securing the fullest and most effective use of the industrial capacity and the man-power available for the production of munitions of all kinds.

The Statement points out that the defence programme necessitates carrying through in a * Statement relating to Defence. (Cmd. 5107.) (London: H.M. stationery Office, 1936.) $3 d$. net. limited period of time measures which will make exceptionally heavy demands upon certain branches of industry and upon certain classes of skilled labour, without impeding the course of normal trade. For its accomplishment, the task demands most careful organisation and the co-operation both of leaders of industry and of trade unions. In place of accumulating vast reserves of munitions, it is proposed to organise industry so that it can rapidly change over at the vital points from commercial to war production should the necessity arise.

The measures proposed by the Government include both the extension and duplication of existing Government factories, and the creation of a reserve source of supply by selecting firms not normally engaged in armaments work who would lay down the plant and machinery for a given output of selected articles, and sufficient orders would be guaranteed in peace time to allow of the requisite training in the work of production. The selected firm, while maintaining and developing its normal civil trade, will agree to use its organisation and commercial structure to set up some measure of munition production and thus create the reserve source of supply.

The organisation thus visualised is designed to overcome so far as possible that time lag in production upon which Major Lefebure laid such stress in his study of scientific disarmament. The plans contemplate, moreover, a measure of control over profits and costs to avoid the piling up of excessive profits which is so liable to characterise arma. ments production in war-time. It also attempts to deal with the equally difficult question of the supply of skilled labour, for which a considerably increased demand is anticipated. 
These questions raise the whole of those problems of labour such as the dilution of labour, the train. ing of unskilled men, the employment of women, which proved so difficult during the Great War. They cannot but have a profound effect on the economic life of the country, and the control of capital and labour involved, the diversion of economic energies may well have disastrous repercussions, unless planned and executed with regard less to the exigencies of the moment than to the ultimate welfare of the nation.

To urge the necessity of an adequate plan and of taking a long-range view is not to ignore or deny the need for improving the present position with reasonable speed. It does, however, point out the evils which may attend hasty decisions regarding the erection, for example, of new works in the strategically suitable depressed areas. Some of these areas owe their present difficulties largely to their association with munition work in time of war, and unless the new developments are wisely conceived as part of a continuous and longrange policy and not merely short-term or emergency measures, any relief they bring to the special areas may be temporary if not illusory and the forerunner of even worse conditions in the future. If we are merely to recreate in the districts dependent on shipbuilding, engineering and the metal industries the inflated surplus of skilled labour which characterised the war years, and rashly denude other areas such as Lancashire, the Midlands and Sheffield, the consequences can scarcely fail to be disastrous from an industrial, as well as an economic, point of view.

Considerations such as these account for the way in which attention has been focused on the third section of the Statement, which deals with the scheme for co-ordinating defence and outlines the appointment and duties of a special minister as Deputy Chairman of the Committee of Imperial Defence and of the Defence Policy and Requirements Committee, to afford some relief to the Prime Minister. The uneasiness and criticism apparent in the recent debate on the White Paper in the House of Commons are in fact to be attributed largely to doubts as to the efficiency of the measures of co-ordination proposed by the Government and whether they will really ensure that the problem of defence is dealt with as a whole and not, as has so often happened in the past, on departmental lines. Having regard to the highly technical nature of modern warfare, with its manifold contacts with and dependence upon geographical and meteorological knowledge, engineering, chemistry and chemical industry, medical science, statistics, psychology and so on, it might have been expected that the new post of Deputy Chairman of the Committee of Imperial Defence would be filled by someone closely in touch with scientific and industrial developments. The Government has apparently decided otherwise, and Sir Thomas Inskip has been called to this onerous post.

Inevitably, perhaps, political events since the publication of the Statement itself led to political aspects being most prominent in the subsequent debate itself, and on the wider issues the speeches in this debate scarcely reached the level of those in the debate on the Ministry of Defence (Creation) Bill on February 14. The speech of Sir Austen Chamberlain on that occasion could scarcely be bettered as an exposition of the fundamental principles. Modern warfare, he pointed out, is an affair of nations, not of armies and of navies, and you must co-ordinate not merely the forces but also the whole of the civil activities of the population.

There is little in the Statement to suggest that the survey of our industrial resources referred to by Sir Austen has been handled with, or that the related question of labour and its use has received, the consideration it demands. We cannot consider recruitment for the services without considering the supplies for the services when they are actively employed, and the people who will be available to provide these supplies. These questions cannot be dealt with by departmental methods. They demand vision and creative minds, and a far. sighted view of national welfare as well as of the immediate and more technical problems of defence.

It is too late in the day to divorce considerations of defence from those of the general welfare. The difficulties which the fighting services find in obtaining recruits of a sufficiently high standard of physique or intelligence are a sufficient reminder that national defence is a matter, not merely of armaments and defence forces, but also of adequate education, nutrition and housing. A defence plan which disregards the general physical and mental welfare of the nation, makes no effort to deal with the insidious effects of long-continued unemploy. ment especially among young persons, and provides inadequately for education or the health and recreation services of the country, will collapse at the first test through the weakening of national morale. 
The supreme need is, as Sir Austen Chamberlain reminded us elsewhere, for a thinking mind on defence. The exigencies and disturbances which have in recent months forced attention on these problems may be welcomed if the lesson of the essential unity of such problems is learnt. We have wasted too much time and thought in attempting to discriminate between combatants and noncombatants and to restrict the methods of warfare, and Major-General Sir Henry Thuillier did good service when in an address at the Royal United Services Institution on February 6 he directed attention to the fallacy of such efforts. Moreover, it is at least arguable, as he pointed out, whether the mowing down of young conscripts by machineguns is any more humane than dropping bombs on the civilian fathers and grandfathers whose cupidity and stupidity provoked war.

It may even be that, as Sir Henry Thuillier suggested, the interests of humanity would be better served if it was known in advance that the direct effects of warfare would not be confined to the combatant services. The realisation that civilians would be exposed to at least the same risks might induce more constructive efforts to establish peace and co-operation, and greater readiness to surrender those national rights which most hinder the working of a system of collective security and constitute the gravest danger to peace.

These are not matters to which the scientific worker can be indifferent. He is concerned both in the elaboration of an adequate policy of national defence as well as in the consequences of a failure to build an adequate structure of peace. He has his part to play both professionally and as a citizen. No service he can render in the solution of the technical problems of defence is, however, more important than that he might give by his insistence on the necessity of planning defence policy in relation to a long-range view of the whole of the nation's resources of materials and manpower ; and on a realistic view of warfare and its consequences which refuses to dissipate energy on side issues, such as the abolition of chemical warfare or the restriction of bombing to indefinable military objectives.

It is in the light of such a long-range policy and of such a spirit of realism that constructive and creative views of international affairs are likely also to emerge ; views which will permit the establishment of a world order in which man may at last enjoy some measure of these powers with which science has endowed him, and which at the moment threaten to be used rather to his downfall.

\section{Anthropology of the Torres Straits: Finis Coronat Opus}

\begin{abstract}
Reports of the Cambridge Anthropological Expedition to Torres Straits

Vol. 1 : General Ethnography. By A. C. Haddon. Pp. xiv $+421+11$ plates. (Cambridge: At the University Press, 1935.) 40s. net.
\end{abstract}

$\mathrm{T}^{\mathrm{H}}$ HIS volume completes the record of the anthropological exploration of Torres Straits undertaken by Dr. Haddon and his companions in 1898, itself the continuation of the author's own earlier work in those islands in 1888. These investigations were supplemented by a trip made in 1914 by Dr. Haddon and his daughter Kathleen -now Mrs. Rishbeth-when some of the previous results were checked, fresh material collected and many photographs taken. Haddon was already middle-aged when he planned and led the Cambridge expedition, and something more than brief thanksgiving to whatever gods there be must be rendered by his companions in the Pacific for the active presence among them to-day of their leader and friend. That no other could have written this volume as it is and ought to be written is manifest, but let us try to see what lay behind, not only the Reports, not only the expedition, but more important than these, the planning of the expedition.

Thirty-five years is so considerable a period that younger anthropologists do not always realise the condition of their science at that time. Until the Torres Straits expedition was planned, all anthropological material other than physical (physical anthropology was already taught in the older universities) had been collected by travellers and missionaries, that is as a by-product of other forms of exploration. It was Haddon who in Great Britain first determined that a special expedition having for its purpose the study of anthropology in the field should come into existence, and, even at that date, appreciated the need to link what we now call social anthropology with psychology in order to attain its full development. 